\title{
Undergraduate accounting students' perceptions of students' empowerment and accounting technical skills: case in Universiti Tenaga Nasional (Uniten), Malaysia
}

\author{
Norlaila Mazura Hj. Mohaiyadin“, Mohd Amran Jaafar, Afiqah Hassan, Amira Rafhan Jafri, \\ Nur Aziannah Abd Azar
}

Department of Accounting, College of Business Management \& Accounting (COBA), Universiti Tenaga Nasional (Uniten), Sultan Haji Ahmad Shah Campus: Bandar Muadzam Shah, Pahang, Malaysia

\section{Email address:}

Norlaila@uniten.edu.my (N. M. Hj. Mohaiyadin)

To cite this article:

Norlaila Mazura Hj. Mohaiyadin, Mohd Amran Jaafar, Afiqah Hassan, Amira Rafhan Jafri, Nur Aziannah Abd Azar. Undergraduate Accounting Students' Perceptions of Students' Empowerment and Accounting Technical Skills: Case in Universiti Tenaga Nasional (Uniten), Malaysia, Social Sciences. Vol. 2, No. 2, 2013, pp. 39-47. doi: 10.11648/j.ss.20130202.13

\begin{abstract}
The aims of the study are to determine: 1) the significant relationships between students' empowerment, accounting technical skills and students' performance, 2) the significant difference between female and male students' perception on empowerment and accounting technical skills and 3) significant differences among Cumulative Grade Point Averages (CGPAs) on the perception of students' empowerment and accounting technical skills. 232 respondents were involved in a study that consists of the third and final year undergraduate accounting students at Universiti Tenaga Nasional (Uniten). The results indicated that there is no significant correlation between the students' empowerment and students' performance but there is a significant correlation between accounting technical skills and students' performance. The results also denoted that there is no significant difference among gender and the level of students' performance on the students' empowerment and accounting technical skills.
\end{abstract}

Keywords: Students' Empowerment, Accounting Technical Skills, Relationships, Differences

\section{Introduction}

Recently, Jawatankuasa Halatuju Program Perakauan from the Department of Higher Education of the Ministry of Education, Malaysia published the third draft of Halatuju Program Perakauan 3 report. According to the draft, the committee has agreed to adopt the Framework-based Teaching of the International Financial Reporting pedagogy that is based on the Student Centered Learning (SCL). Viable training to the academicians is required to achieve the objectives. One of the trainings that the researchers can suggest is on how academicians can encourage and influence students on developing their accounting knowledge, skills and abilities as to align with the committees' requirement.

Most previous scholars were focusing on the student's empowerment and accounting technical skills in separate views. Besides that, the literature in these fields is nevertheless limited in Malaysia. Due to these research gaps, the researchers intend to conduct this study. This study adopted the development of six hypotheses that will be discussed in the next section. This study is a survey of 232 third and final year undergraduate accounting students at Universiti Tenaga Nasional (Uniten) on the perception of student's empowerment and accounting technical skills. This study is designed to identify the combination of student's empowerment and accounting technical skills in the study which leads to the following research questions: 1) Is there any significant relationship between the students' empowerment, accounting technical skills and students' performance, 2) Is there any significant difference between the female and male students' perception on the students' empowerment and accounting technical skills? And 3) Are there any significant differences among Cumulative Grade Point Averages (CGPAs) on the perception of students' empowerment and accounting technical skills?

The aims of the study are to determine: 1) the significant relationships between students' empowerment, accounting technical skills and students' performance, 2) the significant difference between the female and male students' perception on students' empowerment and accounting technical skills 
and 3) significant differences among CGPAs on the perception of students' empowerment and accounting technical skills. The contributions of this study include being a comprehensive guide to the academicians of Uniten to acknowledge the level of students' empowerment and accounting technical skills as well as to deal with different groups of students effectively. It is vital for academicians to recognize the student's ability in order to measure the academic performance and assist them to improve their teaching methods. Besides that, the academicians can encourage their students to improve the accounting technical skills to be well prepared for real world situation. Furthermore, the study aims to assist academicians to identify the level of student's empowerment. Empowerment among students can be developed if the academicians are able to encourage their students to participate actively in the learning process. This study also contributes to the additional literature reviews in this area in Malaysia.

The study begins with the literature review and hypotheses development. It is then followed by the research methodology section to discuss on the instrument that will be used in the study and the respondents involved in the study. After all the data have been collected, the results of the study will be presented in the next chapter. An overall conclusion including the limitations and recommendations will be highlighted in the last section. Thus, the following chapter will elaborate more on the literature review and hypotheses development of the study.

\section{Literature Review and Hypotheses Development}

\subsection{Students' Empowerment}

Empowerment has different definitions from various perceptions by previous researchers. [5] defined empowerment from the perception of nursing education as a personal characteristic that will help new graduates thrive in this challenging healthcare environment and it can be conceptualized as an outcome of their education. According to [11], empowerment is about how to develop knowledge, skills and abilities of the learners to enable them to control and develop their own learning. Besides that, [10] denoted different perceptions of empowerment and stated that the student's empowerment is the extent to which students feel that their instructors/professors: i) permit them to use their own intelligence to solve academic problems, ii) encourage them to handle their own academic problems, iii) trust their intelligence, and iv) allow them freedom in their study.

Moreover, [10] also highlighted that empowerment is a bottom-up process rather than something that can be formulated as a top-down strategy. It is highly recommended that instructors or professors implement transformational leadership before empowering students because it will clarify the educational mission, goals and objectives. In addition, universities or colleges must guide their instructors or professors to clarify the responsibilities and provide a clear direction to the empowered employees. It is also important to identify the student's desire for empowerment before empowering them. [10] further stated that instructors or professors should learn to trust students, provide frequent feedback and make students feel recognized for their empowered behavior.

Meanwhile, [14] described the students' empowerment which is involved in three dimensions: the academic, political and social. The academic empowerment refers to how students develop the ability, confidence and motivation to succeed academically. Political empowerment refers to two fundamental powers either the formal or informal power. The formal power can be realized by having students serve on a disciplinary board or assess their classes as part of the teaching evaluation process and as for the informal power, students may draw attention to a particular issue through means such as striking, thereby influencing school practices or policies. Social empowerment refers to the institutional structures and policies that influence the students' experience [14]. [14] also indicated that the empowered students internalize higher-level cognitive skills and assume greater control over setting their own learning goals, which in turn, improve the students' perceived academic performance.

[10] found that the higher the level of students' empowerment, the higher the level of students' perceived academic performance. [5] found that there are no significant differences in the students' empowerment between groups compared by the school, gender, racial identification, marital status, years in current nursing program, highest educational degree, program type, employment status, employment setting, or nursing organization involvement. [8] stated that the achievement of difference between male and female students significantly favors male students even after accounting for the ability, motivation, other demographic factors, instructional factors and school level factors. Moreover, [8] pointed out that male students have higher final exam scores than the female students although the average GPA of female students enrolled in the program is higher than the male students. [10] found that the higher the level of students' empowerment, the higher the level of students' perceived academic performance. [1] discovered that the respondents with higher CGPA obtained higher scores in the motivation score. According to [19] there were strong and positive relationships between the students' empowerment and students' academic performance. On the other hand, [19] also signified that there are several students who do not have strong empowerment but they perform very well in exam papers.

\subsection{Accounting Technical Skills}

[6] described accounting technical skills as skills specific to accountancy as well as general skills that consist of skills in numeracy, decision making, risk analysis, measurement, reporting, knowledge in legislation and regulatory requirements. Technical skills that have been mentioned by [6] are financial accounting, management accounting, auditing and taxation skills. [4] stated that technical accounting technical 
skills are still important because it will indicate on what they are.

[13] revealed that the majority of respondents agreed on a set of fundamental and expanded knowledge and skills for the training of professional accountants, even though there are some differences in perception of the three groups of respondents (practitioners, educator and students). [13] ranked the top three knowledge components in the United States and China which are financial accounting, finance and taxes.

[6] indicated that the Kazakhstan Institute of Management Economics and Strategic Research (KIMEP) accounting graduates perceived that they are good in professional ethics, interpersonal and communication skills, auditing skills and information development and distribution skills in that order of their ranking which rated auditing skills higher than other technical and functional skills, as the majority of them worked in accountancy firms.

[15] revealed that there is a significant difference among male and female students only in the analytical skills aspect and according to the results, male students have more satisfactions on the skills gained than their female counterparts. Okafor and Egbon (2011) also mentioned that there is no significant difference between the performance of male and female students in all introductory financial accounting courses. Zraa and Imran (u.d.) stated there are some students whose confidence are lacking in their skills, but they are doing very well in exam papers.

[2] identified a positive correlation of accounting subject with the final degree CGPA and it was significant at 0.01 levels. Furthermore, the cumulative GPA is the most important determinant of the students' performance in the fundamentals of financial management course [3].

\subsection{Theoretical Framework}

This study adopted six hypotheses testing. Two of them are to determine the relationship between independent variables which refers to the students' empowerment and accounting technical skills and dependent variable that refers to the academic performance; the CGPAs. Another four hypotheses are purposely to determine the significant differences among gender and CGPAs of students on their perception on the students' empowerment. Therefore, the following framework is prepared to respond to the first aim of the study and the first two hypotheses:

\subsection{Hypotheses Development}

The theoretical framework of the study as presented in Figure 1 will lead to the following first two hypotheses:

H1There is a significant relationship between students' empowerment and students' performance.

H2There is a significant relationship between accounting technical skills and students' performance.

Since the study covers on two types of hypotheses; focus on relationships and comparative study, the following four hypotheses will cover on the different perceptions among the groups within the study:

H3There is a significant difference between the male and female students' perception on students' empowerment.

H4There is a significant difference among the level of CGPAs on the perception of students' empowerment.

H5There is a significant difference between the male and female students' perception on accounting technical skills.

H6There is a significant difference among the level of CGPAs on the perception of accounting technical skills.

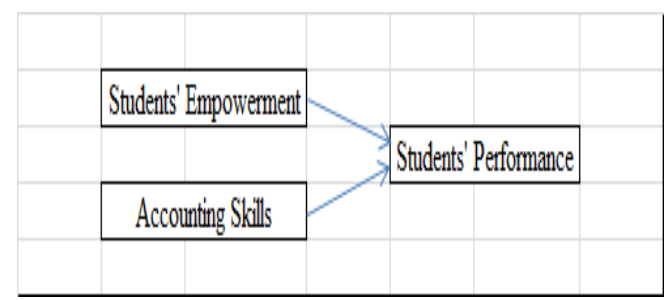

Figure 1. Theoretical Framework of the study.

\section{Research Methodology}

\subsection{Population and Sample}

The sampling method that will be used in this study is simple random sampling. The group of population in this study is undergraduate accounting students in Uniten from the third and final year students for the session 2012/2013. To carry out the procedure, the researchers referred to the academic registrar department to identify the number of population of third and final year undergraduate accounting students. The population of the study consists of 465 third and final year undergraduate accounting students but the researchers managed to collect completed survey from 232 responses. Based on [12] sample size schedule, if the population is 500, a sample size of 217 is required to represent the sample of the population. Researchers are in the opinion that the sample collected is more than sufficient to represent the population with $95 \%$ confidence level and 0.05 degree of accuracy or margin of error. The foundation, first and second year accounting students are not chosen because they are still new in accounting courses and do not have much skills yet especially in auditing and taxation. All of the respondents have an equal chance to respond to the survey.

\subsection{Instrument and Data Collection Procedures}

The questionnaire is adapted from [7] and [17] for the accounting technical skills and [9] for the students' empowerment. The survey consists of three sections; section A requires for the respondents to fill in their demographic profiles such as gender and the level of students' performance which refers to the Cumulative Grade Point Averages (CGPAs). Section B will measure the students' empowerment via 38 items. Section $C$ is on the statement to represent the accounting technical skills with 15 items. The measurement of students' empowerment and accounting technical skills will be based on the Likert scales. The Likert scales will be ranked from 1 to 5 ( $1=$ Strongly Disagree, $2=$ 
Disagree, 3= Neither agree Nor Disagree, 4= Agree and 5= Strongly Agree). Researchers also ran the pilot study with 10 respondents; five from the third year students and another five from the final year undergraduate accounting students. The Cronbach's Alpha (CA) for students' empowerment is 0.952 and accounting technical skills is 0.959 . It shows that the data is excellent and internally consistent.

Researchers obtained the permission from selective lecturers to use 20 minutes of their lecture time to distribute the questionnaire. Once the permissions are granted, researchers conducted a briefing on the title and objectives of the study. Researchers also gave the opportunity for the respondents to inquire about the questionnaire. The respondents were given 20 minutes to respond to the questionnaire. 250 questionnaires were distributed to the respondents but the researchers managed to collect 232 questionnaires as 28 questionnaires could not be used due to incomplete responses.

\section{Results}

\subsection{Preliminary Analyses}

Table 1 projects the number of accounting students based on gender and CGPAs. There are $74.1 \%$ of female and $25.9 \%$ male respondents. The results indicate that the majority of the respondents are female. This is due to the population in Uniten which is conquered by female students and this situation is ordinary nowadays where there are more female students compared to male students in higher learning institutions. 9.9\% managed to obtain CGPAs between 0-2.50, $39.7 \%$ of students obtained $2.51-3.00$ and $29.7 \%$ obtained between 3.01 and 3.50 . 20.7\% contributed to the students who obtained CGPAs of between 3.51 and 4.00.
Table 1. Demographic of Respondent.

\begin{tabular}{llllll}
\hline & & Frequency & $\begin{array}{l}\text { Percent } \\
(\%)\end{array}$ & $\begin{array}{l}\text { Valid } \\
\text { Percent } \\
(\%)\end{array}$ & $\begin{array}{l}\text { Cumulative } \\
\text { Percent (\%) }\end{array}$ \\
\hline Valid & Male & 60 & 25.9 & 25.9 & 25.9 \\
& Female & 172 & 74.1 & 74.1 & 100 \\
& Total & 232 & 100 & 100 & \\
& & & & & \\
& & & & & \\
& $0-2.50$ & 23 & 9.9 & 9.9 & 9.9 \\
& $2.51-3.00$ & 92 & 39.7 & 39.7 & 49.6 \\
Valid & $3.01-3.50$ & 69 & 29.7 & 29.7 & 79.3 \\
& $3.51-4.00$ & 48 & 20.7 & 20.7 & 100 \\
& & & & & \\
\hline
\end{tabular}

There are 38 items classified under the students' empowerment as presented in Table 2. There are eight items that are in negative statement and researchers also recorded the statements. Researchers found that the respondents agreed to the statements except for 11 items which are neutral to the items. The 11 items included "I have the power to make a difference on how things are done in my class", "I can make an impact on the way things are run in accounting class", "I have the opportunity to make important decisions in accounting class", "I cannot influence what happens in accounting class", "My contribution to this accounting class makes no difference", "I have no freedom to choose in accounting class", "I can influence the instructor", "Accounting class is boring", "I feel intimidated by what is required of me in my accounting class", "I lack confidence in my ability to perform the task in accounting class" and "I feel comfortable challenging with my lectures in accounting class".

Table 2. Descriptive Statistics (Students' empowerment).

\begin{tabular}{|c|c|c|c|c|c|}
\hline Items & $\mathbf{N}$ & Minimum & Maximum & Mean & Standard Deviation \\
\hline $\begin{array}{l}\text { I have the power to make a } \\
\text { difference in how things are } \\
\text { done in my class. }\end{array}$ & 232 & 1 & 5 & 3.30 & .814 \\
\hline $\begin{array}{l}\text { I have a choice in the methods } \\
\text { I can use to perform my work. }\end{array}$ & 232 & 1 & 5 & 3.85 & .630 \\
\hline $\begin{array}{l}\text { My participation is important } \\
\text { to the success of the class. }\end{array}$ & 232 & 1 & 5 & 3.69 & .788 \\
\hline $\begin{array}{l}\text { I have freedom to choose } \\
\text { among options in accounting class. }\end{array}$ & 232 & 1 & 5 & 3.64 & .799 \\
\hline $\begin{array}{l}\text { I can make an impact on the } \\
\text { way things are run in accounting class. }\end{array}$ & 232 & 1 & 5 & 3.38 & .840 \\
\hline $\begin{array}{l}\text { Alternative approaches to } \\
\text { learning are encouraged in accounting class. }\end{array}$ & 232 & 2 & 5 & 3.82 & .653 \\
\hline $\begin{array}{l}\text { I have the opportunity to } \\
\text { contribute to the learning of } \\
\text { others in accounting class. }\end{array}$ & 232 & 1 & 5 & 3.69 & .671 \\
\hline $\begin{array}{l}\text { I have the opportunity to } \\
\text { make important decisions in accounting class. }\end{array}$ & 232 & 1 & 5 & 3.44 & .765 \\
\hline $\begin{array}{l}\text { I cannot influence what } \\
\text { happens in accounting class. }\end{array}$ & 232 & 1 & 5 & 2.88 & .882 \\
\hline $\begin{array}{l}\text { I have the power to create a supportive } \\
\text { learning } \\
\text { environment in accounting class. }\end{array}$ & 232 & 2 & 5 & 3.56 & .681 \\
\hline
\end{tabular}




\begin{tabular}{|c|c|c|c|c|c|}
\hline $\begin{array}{l}\text { My contribution to this } \\
\text { accounting class makes no difference. }\end{array}$ & 232 & 1 & 5 & 2.88 & .904 \\
\hline $\begin{array}{l}\text { I can determine how tasks can } \\
\text { be performed. }\end{array}$ & 232 & 2 & 5 & 3.56 & .681 \\
\hline $\begin{array}{l}\text { I make a difference in the } \\
\text { learning that goes on this } \\
\text { accounting class. }\end{array}$ & 232 & 1 & 5 & 3.48 & .744 \\
\hline $\begin{array}{l}\text { I have no freedom to choose } \\
\text { in accounting class. }\end{array}$ & 232 & 1 & 5 & 3.24 & .913 \\
\hline I can influence the instructor. & 232 & 1 & 5 & 3.00 & .830 \\
\hline $\begin{array}{l}\text { I feel appreciated in } \\
\text { accounting class. }\end{array}$ & 232 & 1 & 5 & 3.56 & .730 \\
\hline $\begin{array}{l}\text { The tasks required in my class } \\
\text { are personally meaningful. }\end{array}$ & 232 & 1 & 5 & 3.70 & .752 \\
\hline $\begin{array}{l}\text { I look forward to going } \\
\text { to accounting class. }\end{array}$ & 232 & 1 & 5 & 3.80 & .731 \\
\hline Accounting class is exciting. & 232 & 1 & 5 & 3.74 & .774 \\
\hline Accounting class is boring. & 232 & 1 & 5 & 3.44 & 1.068 \\
\hline Accounting class in interesting. & 232 & 1 & 5 & 3.82 & .732 \\
\hline $\begin{array}{l}\text { The tasks required in my } \\
\text { class are valuable to me. }\end{array}$ & 232 & 1 & 5 & 3.91 & .678 \\
\hline $\begin{array}{l}\text { The information in } \\
\text { accounting class is useful. }\end{array}$ & 232 & 1 & 5 & 4.03 & .627 \\
\hline $\begin{array}{l}\text { Accounting course will help } \\
\text { me to achieve my future goals. }\end{array}$ & 232 & 1 & 5 & 4.06 & .694 \\
\hline $\begin{array}{l}\text { The tasks required in my } \\
\text { accounting class are a waste of my time. }\end{array}$ & 232 & 1 & 5 & 3.69 & 1.068 \\
\hline Accounting class is not important to me. & 232 & 1 & 5 & 3.91 & .978 \\
\hline $\begin{array}{l}\text { I feel confident that I can } \\
\text { adequately perform my duties. }\end{array}$ & 232 & 1 & 5 & 3.71 & .689 \\
\hline $\begin{array}{l}\text { I feel intimidated by what is } \\
\text { required of me in my accounting class. }\end{array}$ & 232 & 1 & 5 & 3.35 & .845 \\
\hline $\begin{array}{l}\text { I posses the necessary skills } \\
\text { to perform successfully in accounting class. }\end{array}$ & 232 & 2 & 5 & 3.69 & .695 \\
\hline $\begin{array}{l}\text { I feel unable to do the work } \\
\text { in accounting class. }\end{array}$ & 232 & 1 & 5 & 3.46 & .970 \\
\hline $\begin{array}{l}\text { I believe that I am capable } \\
\text { of achieving my goals in accounting class. }\end{array}$ & 232 & 1 & 5 & 3.81 & .632 \\
\hline $\begin{array}{l}\text { I have faith in my ability to } \\
\text { do well in accounting class. }\end{array}$ & 232 & 2 & 5 & 3.82 & .659 \\
\hline $\begin{array}{l}\text { I have studied before to } \\
\text { succeed in accounting class. }\end{array}$ & 232 & 1 & 5 & 3.50 & .843 \\
\hline $\begin{array}{l}\text { I lack confidence in my ability } \\
\text { to perform the task in accounting class. }\end{array}$ & 232 & 1 & 5 & 3.27 & 1.015 \\
\hline I feel very competent in accounting course. & 232 & 1 & 5 & 3.58 & .698 \\
\hline $\begin{array}{l}\text { I feel comfortable } \\
\text { challenging with my lectures } \\
\text { in accounting class. }\end{array}$ & 232 & 1 & 5 & 3.34 & .802 \\
\hline $\begin{array}{l}\text { I feel comfortable challenging with } \\
\text { my peers in accounting class. }\end{array}$ & 232 & 1 & 5 & 3.57 & .764 \\
\hline $\begin{array}{l}\text { I feel comfortable } \\
\text { answering questions in } \\
\text { accounting class. }\end{array}$ & 232 & 1 & 5 & 3.57 & .814 \\
\hline
\end{tabular}

Table 3 presents the means and standard deviations for the items classified under the accounting technical skills. The researchers revealed that all items mostly agreed to the items except for "I am able to apply International Financial Reporting Standards in preparing financial statements" with the mean $=3.43$ and standard deviation $=0.775$. The researchers signified that this matter occurs due to the less involvement by the International Financial Reporting Standards (IFRS) in the curriculum in Malaysia since the accounting curriculum in Malaysia is more focused on accounting framework in the Malaysian context. 
Table 3. Descriptive Statistics (Accounting technical skills).

\begin{tabular}{|c|c|c|c|c|c|}
\hline Accounting Technical Skills & $\mathbf{N}$ & Minimum & Maximum & Mean & Standard Deviation \\
\hline \multicolumn{6}{|l|}{ Financial Accounting technical skills } \\
\hline I know how to prepare financial statements & 232 & 1 & 5 & 4.02 & .711 \\
\hline I know how to prepare consolidated accounts & 232 & 1 & 5 & 3.74 & .716 \\
\hline I am ableto analyze financial statements & 232 & 1 & 5 & 3.84 & .672 \\
\hline $\begin{array}{l}\text { I am able to apply relevant Malaysia } \\
\text { Financial Reporting Standards } \\
\text { to prepare financial statements }\end{array}$ & 232 & 1 & 5 & 3.57 & .770 \\
\hline $\begin{array}{l}\text { I am able to apply International Financial } \\
\text { Reporting Standards in preparing } \\
\text { financial statements }\end{array}$ & 232 & 1 & 5 & 3.43 & .775 \\
\hline \multicolumn{6}{|l|}{ Management Accounting technical skills } \\
\hline $\begin{array}{l}\text { I have knowledge of costing to determine, analyze } \\
\text { and control costs }\end{array}$ & 232 & 1 & 5 & 3.86 & .670 \\
\hline I know how to prepare a budget & 232 & 1 & 5 & 3.91 & .683 \\
\hline I know how to appraisean investment & 232 & 1 & 5 & 3.61 & .742 \\
\hline $\begin{array}{l}\text { I know how the fundamentals of management } \\
\text { accounting (planning, control, } \\
\text { decision making, etc.) }\end{array}$ & 232 & 1 & 5 & 3.72 & 699 \\
\hline $\begin{array}{l}\text { I can use live data } \\
\text { to evaluate risks to solve problems }\end{array}$ & 232 & 1 & 5 & 3.56 & .788 \\
\hline $\begin{array}{l}\text { I am able to exercise judgment to solve real-world } \\
\text { problems }\end{array}$ & $d_{232}$ & 1 & 5 & 3.53 & .800 \\
\hline \multicolumn{6}{|l|}{ Auditing Skills } \\
\hline I understand the fundamentals of auditing & 232 & 1 & 5 & 3.75 & .781 \\
\hline $\begin{array}{l}\text { I am able to apply Malaysian Standard on } \\
\text { Auditing (MASA) in my work }\end{array}$ & 232 & 1 & 5 & 3.45 & .810 \\
\hline \multicolumn{6}{|l|}{ Taxation Skills } \\
\hline I understand the fundamentals of taxation & 232 & 2 & 5 & 3.88 & .702 \\
\hline $\begin{array}{l}\text { I am able to apply Income } \\
\text { Tax Act } 1967 \text { in my work }\end{array}$ & 232 & 1 & 5 & 3.75 & .766 \\
\hline
\end{tabular}

Table 4 demonstrates the results obtained from the CA test for the student's empowerment and accounting technical skills. The results indicate that reliabilities for the student's empowerment are 0.901, while the reliabilities for accounting technical skills are 0.921 . The closer the CA is to 1 , the higher the internal consistency reliability (Sekaran and Bougie, 2010). Thus, both results reflected excellent reliabilities which are over 0.80 . In other words, the researchers' data signify the stability and consistency in measurement. Therefore, the results obtained from this research can be used for future studies since the data can be relied on.

Table 4. Reliability for students' empowerment and accounting technical skills.

\begin{tabular}{llll}
\hline & $\begin{array}{l}\text { Cronbach's } \\
\text { Alpha }\end{array}$ & $\begin{array}{l}\text { Cronbach's } \\
\text { Alpha Based on } \\
\text { Standardized Items }\end{array}$ & $\begin{array}{l}\text { N } \\
\text { of Items }\end{array}$ \\
\hline $\begin{array}{l}\text { Students' } \\
\text { Empowerment }\end{array}$ & 0.901 & 0.91 & 38 \\
$\begin{array}{l}\text { Accounting } \\
\text { Technical Skills }\end{array}$ & 0.921 & 0.922 & 15 \\
\hline
\end{tabular}

Based on the results presented in Table 5, the Kolmogorov-Smirnov test indicates that all data including the independent and dependent variables are not normally distributed since $p<0.05$. Therefore, the researchers proceeded with the inferential analyses by using non-parametric analyses such as the Spearman's Rho correlations, Mann-Whitney U and Kruskal-Wallis tests.

Table 5. Tests of Normality.

\begin{tabular}{|c|c|c|c|c|c|c|}
\hline & \multicolumn{3}{|c|}{ Kolmogorov-Smirnov ${ }^{\mathrm{a}}$} & \multicolumn{3}{|c|}{ Shapiro-Wilk } \\
\hline & Statistic & Df & Sig. & Statistic & Df & Sig. \\
\hline Gender & .464 & 232 & .000 & .545 & 232 & .000 \\
\hline CGPA & .242 & 232 & .000 & .868 & 232 & .000 \\
\hline $\begin{array}{l}\text { Students' } \\
\text { Empowerment }\end{array}$ & .066 & 232 & .017 & .987 & 232 & .033 \\
\hline $\begin{array}{l}\text { Acc. } \\
\text { Tech. Skills }\end{array}$ & .094 & 232 & .000 & .964 & 232 & .000 \\
\hline
\end{tabular}

\subsection{Inferential Statistics - Tests for Hypothesis}

The Spearmans' Rho correlations reported in Table 6 indicate that there is no significant correlation between the 
students' empowerment and students' performance. The correlation coefficient between the students' empowerment and students' performance scores is 0.091 which is not significant at $\mathrm{p}>0.05$. This reflects that the students' empowerment does not engage in the students' performance. However, there is a significant correlation between accounting technical skills and students' performance with a correlation coefficient score of 0.163 which is significant at $p<0.05$. This indicates that accounting technical skills do engage in the students' performance. Therefore, the researchers rejected the following hypothesis:

H1There is a significant relationship between students' empowerment and students' performance.

But accepted the following hypothesis;

H2There is a significant relationship between accounting technical skills and students' performance.

Table 6. Correlations

\begin{tabular}{|c|c|c|c|c|c|}
\hline & & & CGPA & $\begin{array}{l}\text { SEM } \\
\text { Transform }\end{array}$ & $\begin{array}{l}\text { Acc. } \\
\text { Tech. } \\
\text { n Skills }\end{array}$ \\
\hline \multirow{9}{*}{$\begin{array}{l}\text { Spearman's } \\
\text { rho }\end{array}$} & \multirow{3}{*}{ CGPA } & $\begin{array}{l}\text { Correlation } \\
\text { Coefficient }\end{array}$ & 1.000 & .091 & $.163^{*}$ \\
\hline & & Sig. (2-tailed) & . & .165 & .013 \\
\hline & & $\mathrm{N}$ & 232 & 232 & 232 \\
\hline & \multirow{3}{*}{$\begin{array}{l}\text { Students' } \\
\text { Empowerment }\end{array}$} & $\begin{array}{l}\text { Correlation } \\
\text { Coefficient }\end{array}$ & .091 & 1.000 & $.521^{* *}$ \\
\hline & & Sig. (2-tailed) & .165 & . & .000 \\
\hline & & $\mathrm{N}$ & 232 & 232 & 232 \\
\hline & \multirow{3}{*}{$\begin{array}{l}\text { Acc. } \\
\text { Tech. Skills }\end{array}$} & $\begin{array}{l}\text { Correlation } \\
\text { Coefficient }\end{array}$ & $.163^{*}$ & $.521^{* *}$ & 1.000 \\
\hline & & Sig. (2-tailed) & .013 & .000 & . \\
\hline & & $\mathrm{N}$ & 232 & 232 & 232 \\
\hline
\end{tabular}

*. Correlation is significant at the 0.05 level (2-tailed).

**. Correlation is significant at the 0.01 level (2-tailed).

a. Lilliefors Significance Correction

Table 7 shows the results obtained from the MannWhitney $U$ tests. The outputs indicate that there is no significant difference between the male and female students' empowerment with $\mathrm{U}=4406.000, \mathrm{z}=-1.685, \mathrm{p}>0.05$ and accounting technical skills with $U=4933.500, z=-0.507, p>$ 0.05 . The effect sizes for both sizes are too small, less than 0.2 . Thus, the researchers rejected the following two hypotheses:

H3There is a significant difference between the male and female students' perception on students' empowerment.

H5There is a significant difference between the male and female students' perception on accounting technical skills.
Table 7. Mann-Whitney U test (gender based).

\begin{tabular}{lll}
\hline & $\begin{array}{l}\text { Students' } \\
\text { Empowerment }\end{array}$ & $\begin{array}{l}\text { Accounting } \\
\text { Technical Skills }\end{array}$ \\
\hline Mann-Whitney U & 4406.000 & 4933.500 \\
Wilcoxon W & 6236.000 & 19811.500 \\
Z & -1.685 & -.507 \\
Asymp. Sig. (2-tailed) & 0.092 & 0.612 \\
Effect Size & -0.007 & -0.002 \\
\hline
\end{tabular}

Table 8 indicates that there are no significant differences among the levels of CGPAs on the perception of students' empowerment with $\mathrm{X} 2(3, \mathrm{~N}=232)=3.620, \mathrm{p}>0.05$. However, in the issue of accounting technical skills with $\mathrm{X} 2$ $(3, N=232)=7.838, p>0.05$, the researchers are in the opinion that the $\mathrm{p}$ value supposedly be $<0.05$ but the researchers decided that the $\mathrm{p}$ value is more than 0.05 . This is due to the effect of the sizes for the variable that is too small. To prove more about the $\mathrm{p}$ value of the perception on accounting technical skills based on CGPAs, the researchers ran through the Bonferonni correction procedure as presented in Table 8: Panel A. The researchers found that all pairs of CGPAs are significant on each other on the perception of accounting technical skills. Therefore, the researchers rejected the following hypotheses:

H4There is a significant difference among the levels of CGPAs on the perception of students' empowerment.

H6There is a significant difference among the levels of CGPAs on the perception of accounting technical skills.

Table 8. Kruskal-Wallis test (CGPAs based).

\begin{tabular}{lll}
\hline & $\begin{array}{l}\text { Students' } \\
\text { Empowerment }\end{array}$ & $\begin{array}{l}\text { Accounting } \\
\text { Technical Skills }\end{array}$ \\
\hline Chi-square & 3.620 & 7.838 \\
Df & 3 & 3 \\
Asymp. Sig. & 0.306 & 0.049 \\
Effect Size & 0.016 & 0.034 \\
\hline
\end{tabular}

Panel A: $U, z, p$-values and Holmes Correction on the perception of Accounting Skills (CGPAs).

\begin{tabular}{|c|c|c|c|c|}
\hline & U-value $e^{z \text {-valu p-val }}$ & 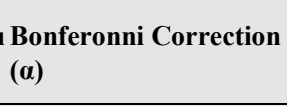 & $\begin{array}{l}\text { Signi } \\
\text { Not } \\
\text { cant }\end{array}$ & $\begin{array}{l}\text { ficant or } \\
\text { ignifi- }\end{array}$ \\
\hline $\begin{array}{l}\text { Poor vs. } \\
\text { Good }\end{array}$ & $531.500-2.3670 .02$ & 0.01 & $\begin{array}{l}\text { Not } \\
\text { cant }\end{array}$ & Signifi- \\
\hline $\begin{array}{l}\text { Average } \\
\text { vs. Good }\end{array}$ & $\begin{array}{lll}2608.50 & -1.9350 .05 \\
0 & \end{array}$ & 0.01 & $\begin{array}{l}\text { Not } \\
\text { cant }\end{array}$ & Signifi- \\
\hline $\begin{array}{l}\text { Poor vs. } \\
\text { Excellent }\end{array}$ & $400.000-1.8700 .06$ & 0.01 & $\begin{array}{l}\text { Not } \\
\text { cant }\end{array}$ & Signifi- \\
\hline $\begin{array}{l}\text { Average } \\
\text { vs. Excel- } \\
\text { lent }\end{array}$ & $\begin{array}{ll}1906.50 & -1.3260 .19\end{array}$ & 0.02 & $\begin{array}{l}\text { Not } \\
\text { cant }\end{array}$ & Signifi- \\
\hline $\begin{array}{l}\text { Poor vs. } \\
\text { Average }\end{array}$ & $873.500-1.2920 .20$ & 0.03 & $\begin{array}{l}\text { Not } \\
\text { cant }\end{array}$ & Signifi- \\
\hline $\begin{array}{l}\text { Good } \\
\text { vs. } \\
\text { Excellent }\end{array}$ & $\begin{array}{ll}1603.50 & -0.2910 .77\end{array}$ & 0.05 & $\begin{array}{l}\text { Not } \\
\text { cant }\end{array}$ & Signifi- \\
\hline
\end{tabular}

\section{Discussion}


The Spearmans' Rho correlations reported that there is no significant correlation between the students' empowerment and students' performance. This result is not consistent with [10] and [19] who reported that the higher the level of students' empowerment, the higher the level of students' perceived academic performance. This consistency may be due to the different respondents used for the study. However, there is a significant correlation between accounting technical skills and students' performance. The result of the study is consistent with [2] and [3] who discovered a positive correlation of accounting subject with the final degree CGPA and the cumulative GPA is the most important determinant of the students' performance in the fundamentals of financial management course.

The outputs indicate that there is no significant difference between the male and female students' empowerment and accounting technical skills. On the other hand, the outputs also indicate that there are no significant differences among the levels of CGPAs on the perception of students' empowerment and accounting technical skills. These matters are consistent with [5] to state that there are no significant differences in the students' empowerment between groups compared by the school, gender, racial identification, marital status, years in current nursing program, highest educational degree, program type, employment status, employment setting or nursing organization involvement. However, in addition to the existing literature, this study revealed that there are significant differences among the levels of CGPAs on the students' performance. In the issue of accounting technical skills, the results of the study contribute new findings to be added to the existing literature. However, this finding is different if compared to the findings made by [15] who revealed that there is a significant difference among male and female students that focuses on the analytical skills aspect and [13] revealed that there are some differences in the perceptions of the three groups of respondents (practitioners, educator and students).

\section{Conclusion, Limitations and Recom- mendations}

This study is a survey of 232 third and final year undergraduate accounting students at Universiti Tenaga Nasional (Uniten) on the perception of student's empowerment and accounting technical skills. The aims of the study are to determine: 1) the significant relationships between students' empowerment, accounting technical skills and students' performance, 2) the significant difference between female and male students' perception of students' empowerment and accounting technical skills and 3) significant differences among CGPAs on the perception of students' empowerment and accounting technical skills. The sampling method that will be used in this study is simple random sampling. The group of population in this study is undergraduate accounting students in Uniten from the third and final year students for the session 2012/2013. The questionnaire is adapted from [7] and [17] for the accounting technical skills and [9] for the students' empowerment. The Spearmans' Rho correlations reported that there is no significant correlation between the students' empowerment and students' performance but there is a significant correlation between accounting technical skills and students' performance. The outputs indicate that there is no significant difference between the male and female students' empowerment and accounting technical skills. On the other hand, the outputs also indicate that there are no significant differences among the levels of CGPAs on the perception of students' empowerment and accounting technical skills.

Researchers have determined only two limitations of this study. Firstly, the sample for this study is only within the Uniten boundaries that could not be generalized onto others. Secondly, the total of female respondents is greater than male respondents. This is because the nature sample of female population itself is highly larger than the male population. The researchers have some recommendations for future researches. Based on the findings, the researchers recommended for the study to be extended to the entire Uniten that may investigate on the perceptions of non-accounting students on the students' empowerment and accounting technical skills among them. Besides that, by using the instrument, it could be applied to different research methods i.e. focus group of the sample or other research analyses i.e. regression.

\section{References}

[1] Aida, S.M.Y. \& Wan, Z.W.A. (2009). Motivation in the Learning of Mathematics. European Journal of Social Sciences, 7(4), pp. 93-101.

[2] Alfan, E. \& Othman, M. N. (2005). Undergraduate Students' Performance: The Case of University of Malaya. Quality Assurance in Education, 13(4), pp. 329-343.

[3] Al-Tamimi, H. A. H. \& Al-Shayeb, A. R. (2002). Factors Affecting Student Performance in the Introductory Finance Course. Journal of Economic \& Administrative Sciences, 18(2), pp. 1-11.

[4] Blanthorne, C., Bhamornsiri, S. \& Guinn, R. E. (2005). Are Technical Skills Still Important? The CPA Journal, 75(3), pp. 64-65.

[5] Bosley, C. L. M. (2005). Organizational Culture and Students' Empowerment in Baccalaureate Nursing Programs.

[6] Chaker, M. N. \& Abdullah, A. (2011). What Accountancy Skills Are Acquired at College? International Journal of Business and Social Science, 2(18), pp. 193-199.

[7] Deepe, L. A, Sonderegger, E. O, Stice, J. D, Clarck, D. C. \& Streuling, G. F. (1991). Emerging Competencies for the Practice of Accountancy. Journal of Accounting Education, 9, pp. 257-290.

[8] Dennis, A., Cakir, H., Korkmaz, A., Duffy, T., Bichelmeyer, B. \& Bunnage, J. A. (u.d.). Student Achievement in a Blended-Learning Environment: Lessons from the Cisco Networking Academy. 
[9] Frymier, A. B., Shulman, G. M. \& Houser, M. (1996). The Development of a Learner Empowerment Measure. Communication Education, 45(3), pp. 181.

[10] Gill, A., Mand, H. S., Culpepper, A., Mathur, N. \& Buthani, S (2011). The Relations of Transformational Leadership and Empowerment with Student Perceived Academic Performance: A Study among Indian Commerce Students. Business and Economics Journal, 34, pp. 1-9.

[11] Harvey, L. (2004). Analytical Quality Glossary, Quality Research International. Retrieved 14 April, 2012, from http://www.qualityresearchinternational.com/glossary/empo werment.htm.

[12] Krejcie, R. D. and Morgan, D. W. (1970). Determining Sample Size for Research Activities. Educational Psychological Measurement, 30, pp. 607-610.

[13] Lin, Z. J., Xiong, X. \& Liu, M. (2005). Knowledge base and skill development in accounting education: Evidence from China. Journal of Accounting Education, 23, pp. 149-169.

[14] McQuillan, P. J. (2005). Possibilities and Pitfalls: A Comparative Analysis of Students' empowerment. American
Educational Research Journal, 42(4), pp. 639670.

[15] Mojtahedzadeh, V., Tabari, S. H. A. \& Badr, M. A. (2010). Comparison between Accounting, B. A. and T. E. Students on the Impact of Their Majors on Personal Satisfaction in Acquiring General Skills. International Review of Business Research Papers, 6(5), pp. 181-195.

[16] Okafor, C. A. \& Egbon, O. (2011). Academic Performance of Male versus Female Accounting Undergraduate Students: Evidence from Nigeria. Higher Education Studies, 1(1), pp. 9-19.

[17] Palmer, K. N, Ziengenfuss, D. E \& Pinsker, R. E. (2004). International knowledge, skills and abilities of auditors/accountants: Evidence from recent competency studies. Managerial Auditing Journal, 19(7), pp. 889-896.

[18] Sekaran, U. and Bougie, R. (2010). Research Methods for Business: A Skills Building Approach, 5th Edition. New York: John Wiley \& Sons.

[19] Zraa, W. \& Imran, S. (u.d.). The relationships between students' empowerment, students performance, accounting course perceptions and classroom instruction in accounting. 